\title{
Respiratory Syncytial Virus Groups A and B in Porto Alegre, Brazil, from 1990 to 1995 and 1998
}

\author{
Selir M Straliotto/ ${ }^{+}$, Sandra M Nestor, Marilda M Siqueira* \\ Fundação Estadual de Produção e Pesquisa em Saúde, Seção de Virologia, Laboratório Central, Rua Domingos \\ Crescêncio 132, 90650-090 Porto Alegre, RS, Brasil *Departamento de Virologia, Instituto Oswaldo Cruz, \\ Rio de Janeiro, RJ, Brasil
}

We analyzed the respiratory syncytial virus (RSV) groups and their epidemiological pattern that were detected over the course of seven years in southern Brazil. The two RSV groups co-circulated each year, but frequencies of groups $A$ and B varied both between and within yearly outbreaks. In 1991, group A predominated over group B $(p=0.0016)$. RSV outbreaks analyzed showed a temperature-dependent pattern and no association with rainfall, similarly to other countries from southern South America. Knowledge of the variants is important in terms of both diagnosis and definition of a vaccine composition.

Key words: respiratory syncytial virus - groups respiratory syncytial virus - acute respiratory infection Porto Alegre - Brazil

Respiratory syncytial virus (RSV) occurs annually in the winter and early spring months in temperate climates and spreads extensively among infants and children in the community (Brodie et al. 1973, Anderson et al. 1990a). Epidemics of RSV infection have been inversely related to temperature (John et al. 1991) and to the number of hours of sunshine (Orstavick et al. 1980) and were directly associated with differences in rainfall (de Silva \& Hanlon 1986). RSV infection in young children is a worldwide problem, mainly causing acute bronchiolitis but also other acute upper-and lower-respiratory tract infections (Hierholzer \& Tannock 1986). In both tropical and developing countries RSV is an important pathogen and a frequent cause of hospital admission of young children, but little is known about its epidemiology (Weber et al. 1998).

Two major groups of RSV strains with antigenic differences in the $\mathrm{F}$ and $\mathrm{G}$ proteins and other internal viral proteins (Mufson 1985, Norby et al. 1986) have been identified using panels of monoclonal antibodies (Mabs): group A, represented by the Long strain, and group B, represented by the 18537 strain (Anderson et al. 1985, Akerlind \& Norrby 1986). Several recent studies from different geographic areas have analyzed the grouping of clinical RSV isolates and have shown that both

\footnotetext{
${ }^{+}$Corresponding author. Fax: +55-51-223.3727. E-mail: smstra@bol.com.br

Received 15 February 2000

Accepted 17 October 2000
}

strains tend to circulate simultaneously, although the relative proportions may vary from year to year (Mufson et al. 1988, Monto \& Homit 1989, Hall et al. 1990, Gilchrist et al. 1994).

In Brazil, studies have identified the simultaneous circulation of the RSV groups in different years in the northern, southeastern, and southern regions (Siqueira et al. 1991, Mello \& Silva 1992, Straliotto et al. 1994), but no epidemiological pattern for RSV circulation has been established for other regions of the country. In addition to Brazil's regional climatic diversity, which influences the epidemiological characteristics of viral ARIs, there is a lack of broader regional surveys to characterize RSV outbreaks in the community. Knowledge of the antigenic variants is important for the diagnosis and definition of a vaccine composition. In addition, knowledge of local RSV epidemiology requires the conduct of longitudinal studies dealing with the prevalence of RSV antigenic groups and their relationship with clinical features.

In this study, we used Mabs both to characterize the RSV group and to determine the epidemiological pattern of RSV groups detected during the sevenyear study period in southern Brazil. The study group included infants and children with acute or lower respiratory tract diseases in whom RSV was detected from nasopharyngeal secretions (NPS) tested from 1990 to 1995 and 1998. The infants and children were treated in both out-patient clinics and in-patient pediatric hospital services in the city of Porto Alegre in southern Brazil. More elaborate details on the sampling have alredy been reported in congresses (Straliotto et al. 1993, 1994). We began the study by collecting samples from May to Septem- 
ber 1990, May to December 1992, and every month of the year after 1992 until 1998. Samples yielding RSV detection from $1996(\mathrm{n}=176)$ and $1997(\mathrm{n}=$ 129) were not grouped due to power failure problems with the freezers.

Nasopharyngeal secretion samples were collected from children under 5 years of age and processed for rapid diagnosis by immunofluorescence (IFAT) (Anderson et al. 1985). All samples were also tested by IFAT for adenovirus, influenza and parainfluenza virus. Duplicate slides with cells from nasopharyngeal secretions were prepared and stored routinely at $-20^{\circ} \mathrm{C}$ for RSV grouping. RSV groups were identified by indirect immunofluorescence with antibodies specific to group A (92-11c) and group B (102-10b) (Siqueira \& Nascimento 1990). These reagents were kindly supplied by $\mathrm{Dr}$ Larry Anderson (Centers for Disease Control, Atlanta, USA). As in previously published reports (Taylor et al. 1989, Russi et al. 1989, Siqueira \& Nascimento 1990), we grouped RSV using IFAT on NPS cells that were stored frozen at $-20^{\circ} \mathrm{C}$ (Freymuth et al. 1991).
Meteorological data were obtained from the 8th Meteorology District, Porto Alegre, Brazil.

The total number of children examined in this study was 2,337 . Of these, $492(21 \%)$ were positive for RSV. A total of 331 RSV-positive NPS slides were investigated for characterization of RSV groups, of which $71.3 \%$ (236) were group A and $28.7 \%$ (95) group B. The peak incidence in the outbreaks occurred regularly in July or August, except in 1993. The two RSV groups co-circulated in the susceptible population each year, but frequencies of groups $\mathrm{A}$ and $\mathrm{B}$ varied both between and within yearly outbreaks. In 1991, group A (90.4\%) predominated over group B $(9.6 \%)(p=0.0016)$. In the other years, the two groups were present in almost equal proportions. Although infection prevalence was higher in the winter (May to September), as in temperate climates, the virus also circulated throughout the summer (January to April) in 1998. Group A showed a regular peak frequency in the months of July and August, while the peak for group B varied from year to year. In the summer of 1998, only group B was detected. Monthly distribution of RSV groups is shown in Fig. 1.

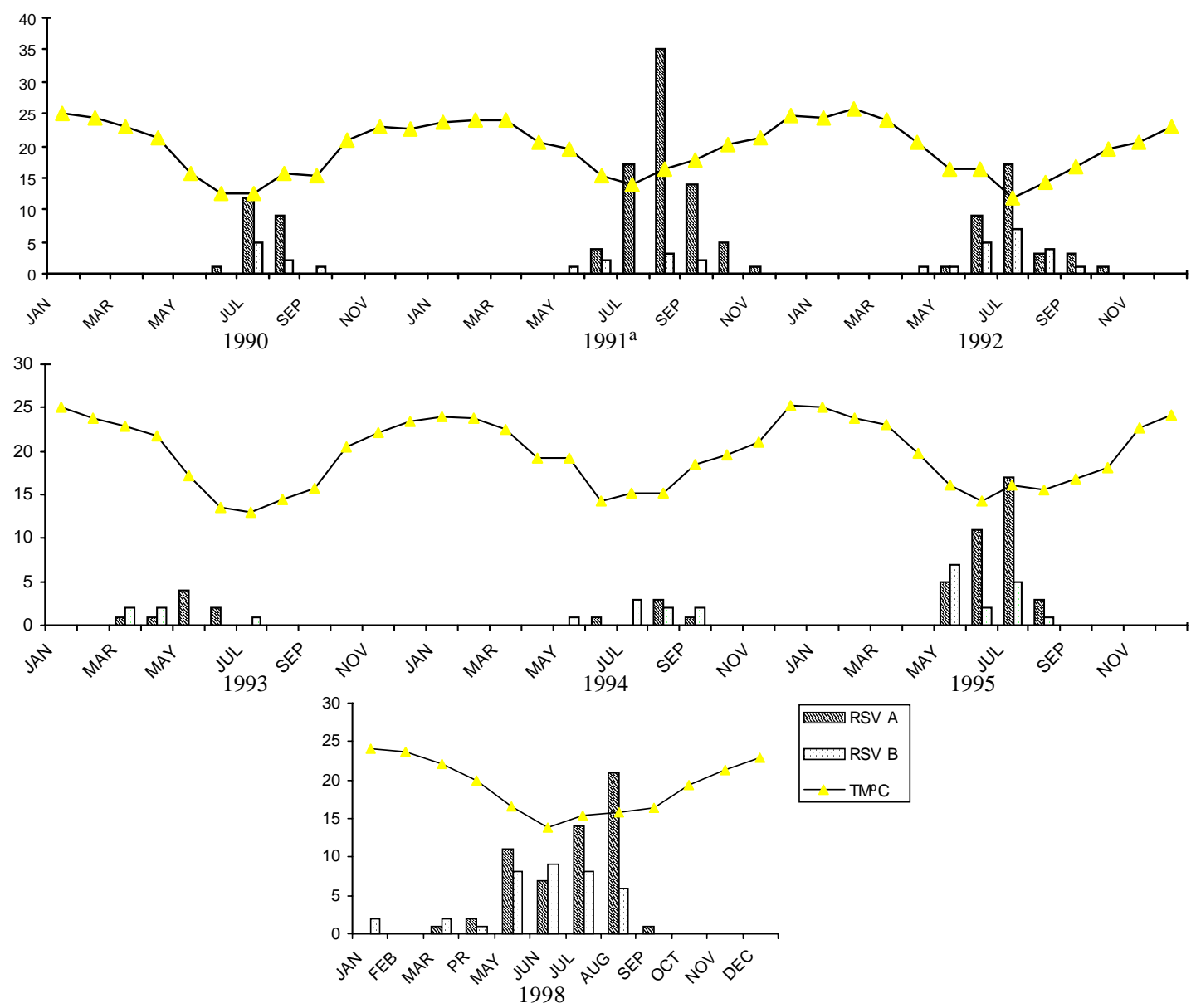

Fig. 1: seasonality in respiratory sincytial virus (RSV) groups and mean monthly temperature. a: frequency of RSV group A over group $\mathrm{B}(\mathrm{p}=0.0016) ; \mathrm{TM}^{\circ} \mathrm{C}$ : montly temperature in Celsius degree 
Duration of the epidemic varied from year to year, although detection time for each RSV group was similar within the epidemic. When all positive samples detected throughout the seven-year period were combined by month of occurrence, the B strain appeared to be detected earlier in the season than A (Fig. 2).

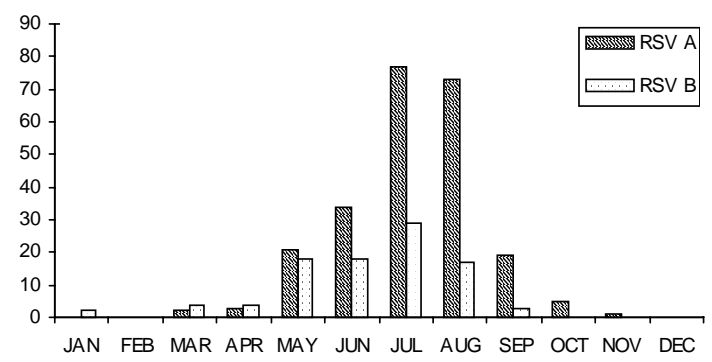

Fig. 2: respiratory syncytial virus (RSV) groups $A$ and $B$ by month for the seven years in which the strains co-circulated.

Comparison of this study with three previous studies on group frequencies in Finland, the United States of America, and France confirms co-circulation of the two RSV groups each year, with different temporal RSV patterns and variable prevalence rates of the RSV groups in these countries in 1990 (Hall et al. 1990, Warris 1991, Freymuth et al. 1991). In addition, the comparison of studies on RSV groups in Brazil with those from neighboring countries in southern South America (Russi et al. 1989, Salomón et al. 1991, Siqueira et al. 1991), we observe the occurrence of the same temporal patterns for RSV, with a large predominance of group B in children from Uruguay, Argentina, and Brazil in 1987. However, phylogenetic analysis showed that the group A and group B viruses were located in multiple lineages and that very similar viruses were isolated at different times and from geographically distant sites (Coggins et al. 1998).

RSV outbreaks analyzed in this study and those from other countries in southern South America (Weber et al. 1998) showed a temperature-dependent pattern and no association with rainfall (data not shown). Different patterns were noted when comparing our results with those of RSV outbreaks from northeastern Brazil, which occur in the first half of the year (Mello WA 1999, pers. commun.). Studies conducted in large countries (Anderson et al. 1990b) suggest that RSV outbreaks are community-related and possibly of regional occurrence, but not a national phenomena. In Brazil, there is a lack of regional studies to support such conclusions.

Our data and those of others (Washburne et al. 1992, Gilchrist et al. 1994) indicated RSV circula- tion within the community throughout the year, including the summer. Observing the RSV groups, we noted that only group B circulated during the warm months (summer) in 1998, and that it generally appeared earlier (earlyspring) than the A group. These data show that the virus circulated throughout the entire year, but with antigenic variations during the outbreak. Previous studies have show that RSV group antigenic variation has a significant effect on virus epidemiology, suggesting that the age distribution in reinfections and the associated typing results could reflect the immune status of the patients and the virus group variation (Waris 1991). However, has no relationship with disease severity and/or clinical presentation, as based on findings from hospitalized patients with laboratoryconfirmed RSV infection during the summer or winter (Washburne et al. 1992).

In the southernmost Brazilian State, Rio Grande do Sul, we identified two circulation patterns for RSV groups during annual outbreaks, similar to reports by Hall et al. (1990). In $85.7 \%$ of the whole period when outbreaks were investigated (six years) there were similar incidence rates of groups $\mathrm{A}$ and $\mathrm{B}$, whereas in $14.3 \%$ (one year) of the sevenyear surveillance study group A predominated over group B. Predominance of group B over group A, was not observed during our study period, although we cannot rule out the possibility of such an event had occurred during the outbreaks through 19961997, when the group typing could not be performed. This antigenic heterogeneity may play a role in reinfection and in the incomplete immunity seen following RSV infection, and should be considered in the design of both vaccines and diagnostics tests.

Antigenic and genetic diversities of the G protein occurs within-and-between the two RSV groups (Johnsons et al. 1987, Sullender et al. 1993, Coggins et al. 1998). Hypermutation events in the $\mathrm{G}$ glycoprotein are relevant for the generation of antigenic variants (Martinez et al. 1997), but the role of antigenic variation in RSV reinfection is not known precisely. RSV outbreaks need to be characterized in terms of both grouping and genotyping, in order to fully understand protective immunity after natural infection as well as protective immunity conferred by candidate vaccines (Peret et al. 1998). Genetic diversity among RSV groups A and B was not sought in the present investigation, but future studies are planned dealing with this particular subject.

\section{REFERENCES}

Akerlind B, Norrby 1986. Occurrence of respiratory syncytial virus subtypes A and B strains in Sweden. J Med Virol 19: 241-247. 
Anderson LJ, Hendry RM, Pierik LT, Tsou C, McIntosh Y 1990b. Multicenter study of strains of respiratory syncytial virus. J Infect Dis 16: 687-692.

Anderson LJ, Hierholzer JC, Tsou C, Hendry RM, Fernie BF, Stone Y, McIntosh K 1985. Antigenic characterization of respiratory syncytial virus strains with monoclonal antibodies. J Infect Dis 151: 626-633.

Anderson LJ, Parker RA, Strikas RL 1990a. Association between respiratory syncytial virus outbreaks and lower respiratory tract deaths of infants and young children. J Clin Microbiol 161: 640-646.

Brodie HR, Spence LP, Path MRC 1973. Respiratory syncytial virus infections in children in Montreal: a retrospective study. British Med J 109: 796-798.

Coggins WB, Lefkowitz EJ, Sullender WM 1998. Genetic variability among group A and B respiratory syncytial viruses in a children's hospital. J Clin Microbiol 36: 3552-3557.

De Silva LM, Hanlon MG 1986. Respiratory syncytial virus: a report of a 5-year study at a childen's hospital. J Med Virol 19: 299-305.

Freymuth F, Petitjean J, Pothier P, Brouard J, Norrby E 1991. Prevalence of respiratory syncytial virus subgroups A and B in France from 1982 to 1990 . J Clin Microbiol 29: 653-655.

Gilchrist S, Torok TJ, Gary HE, Alexander Jr JP, Anderson LJ 1994. National surveillance for respiratory syncytial virus, United States, 1985-1990. J Infect Dis 170: 986-990.

Hall CB, Walsh EE, Schnabel KC, Long CE, Mc Connochie KM, Hildreth SM, Anderson LJ 1990. Occurrence of groups A and B of respiratory syncytial virus over 15 years: associated epidemiologic and clinical characteristics in hospitalized and ambulatory children. J Infect Dis 162: 1283-1290.

Hierholzer JC, Tannock GA 1986. Respiratory syncytial virus: a review of the virus, its epidemiology, immune response and laboratory diagnosis. Aust Paediatr J 22: 77-82.

John TJ, Cherian T, Steinhoff MC, Simões EA, John M 1991. Etiology of acute respiratory infection in children in tropical southern India. Rev Infect Dis 13(Suppl. 6): S463-S469.

Johnson PR, Olmsted RA, Prince GA, Murphy BR, Alling DW, Walsh EE, Collins PL 1987. Antigenic relatedness between glycoproteins of human respiratory syncytial virus subgroups $\mathrm{A}$ and $\mathrm{B}$ : evaluation of contributions of $\mathrm{F}$ and $\mathrm{G}$ glycoproteins to immunity. J Virol 61: 2623-2628.

Martinez I, Dopazo J, Melero JA 1997. Antigenic structure of the human respiratory syncytial virus $\mathrm{G}$ glycoprotein and relevance of hypermutation events for the generation of antigenic variants. J Gen Virol 78: 2419-2429.

Mello WA, Silva C 1992. Epidemiological aspects of RSV subgroups in Belém, Brazil. Boletin Latinoamericano 1: 8.

Monto AS, Ohmit S 1990. Respiratory syncytial virus in a community population: circulation of subgroups A and B since 1965. J Infect Dis 161: 781-783.

Mufson MA, Belshe RB, Orvell C, Norrby E 1988. Respiratory syncytial virus epidemics: variable domi- nance of subgroups A and B strains among children, 1981-1986. J Infect Dis 157: 143-148.

Mufson MA, Orvell C, Rafnar B, Norrby E 1985. Two distinct subtypes of human respiratory syncytial virus. J Gen Virol 66: 2111-2124.

Norby E, Mufson M, Sheshberadaran I 1986. Structural differences between subtype A and B strains of respiratory syncytial virus. J Gen Virol 67: 2721-2729.

Orstavick I, Carlsen KH, Halvorsen K 1980. Respiratory syncytial virus infections in Oslo 1972-1978. I. Virological and epidemiological studies. Acta Paediatr Scand 69: 717-722.

Peret TCT, Hall CB, Schnabel KC, Golub JÁ, Anderson LJ 1998. Circulation patterns of genetically distinct group A and B strains of human respiratory syncytial virus in a community. J Gen Virol 79: 2221-2229.

Russi JC, Delfraro A, Arbiza JR, Chiparelli H 1989. Antigenic characterization of respiratory syncytial virus associated with acute respiratory infections in Uruguayan children from 1985 to 1987 . J Clin Microbiol 27: 1461-1466.

Salomón HE, Avila MM, Cerqueiro MC, Orvell C, Weissenbacher M 1991. Clinical and epidemiologic aspects of respiratory syncytial virus antigenic variants in Argentinian children. J Infect Dis 163: 1167.

Siqueira MM, Nascimento JP 1990. Respiratory syncytial virus: occurrence of subgroups A and B strains in Rio de Janeiro. Mem Inst Oswaldo Cruz 85: 483484.

Siqueira MM, Nascimento JP, Anderson LJ 1991. Antigenic characterization of respiratory syncytial virus group A and B isolates in Rio de Janeiro, Brazil. J Clin Microbiol 29: 557-559.

Straliotto SM, Nestor SM, Cunha MLT, Fischer GB, Krause OP, Muller RL, Siqueira MM 1993. Prevalência de virus respiratórios em serviços de pronto atendimento de Porto Alegre - 1991 e 1992. Encontro de Virologia, Porto Alegre, Brazil.

Straliotto SM, Roitman B, Lima JB, Fischer GB, Siqueira MM 1994. Respiratory syncytial virus (RSV) bronchiolitis: comparative study of RSV groups A and B infected children. Rev Soc Bras Med Trop 27: 14.

Sullender WM, Sung L, Anderson LJ 1993. Analysis of respiratory syncytial virus genetic variability with amplified cDNAs. J Clin Microbiol 31: 224-1231.

Taylor CE, Morrow S, Scott M, Young B, Toms GL 1989. Comparative virulence of respiratory syncytial virus subgroups A and B. Lancet 8: 777-778.

Waris M 1991. Pattern of respiratory syncytial virus epidemics in Finland: two-year cycles with alternating prevalence of groups A and B. J Infect Dis 163: 464-469.

Washburne JF, Bocchini JÁ, Jamison RM 1992. Summertime respiratory syncytial virus infection: epidemiology and clinical manifestations. Southern Medical J 85: 579-583.

Weber MW, Mulholland KE, Greenwood BM 1998. Respiratory syncytial virus infection in tropical and developing countries. Trop Med Internat Health 3: $268-280$ 